\title{
Public relations discourse, ethical propaganda and collective identity in Luis Buñuel's Spanish Civil War films
}

Francisco-Javier Ruiz del Olmo ${ }^{\mathrm{a} *}$, Jordi Xifra ${ }^{\mathrm{b} * *}$

${ }^{a}$ Department of Advertising and Audiovisual Communication, University of Malaga, Spain

${ }^{\mathrm{b}}$ Department of Communication, Pompeu Fabra University, Barcelona, Spain

* Tel.: + 349521332 80; e-mail: fjruiz@uma.es

** Tel.: + 349354214 84; e-mail: jordi.xifra@upf.edu

\begin{abstract}
The Spanish Civil War occupies a very relevant place in the collective memory of Europeans. At the beginning of the War, Spanish filmmaker Luis Buñuel received instructions from the Spanish Ministry of Foreign Affairs to return to Paris and assist the Spanish embassy in various types of counterintelligence and propaganda work. As part of this, Buñuel organized and assembled footage of the Republicans. Unlike other productions compiled in Spain, the Republican propaganda films made in Paris were generally addressed at audiences in different European countries with the aim of breaking the doctrine of non-intervention in the conflict, and they reflect Buñuel's theories and conception of the documentary films. These films represent good examples of ethical propaganda and their aim was more informative than manipulative. From this standpoint, and in accordance with other research on public relations discourse and film, we argue that the films supervised by Buñuel in this period, and especially the most noteworthy documentary España leal en armas (1937), are examples of public relations films in wartime.
\end{abstract}


Keywords: Luis Buñuel; Public relations films; Propaganda films; España leal en armas; Second Spanish Republic; History of public relations.

\section{Collective memory, public relations and filmmaking}

Culture is frequently understood as "an historically transmitted pattern of meaning embodied in symbols, a system of inherited conceptions expressed in symbolic forms by means of which men communicate, perpetuate and develop their knowledge about and attitudes towards life" (Geertz, 1979, p. 83). From this standpoint, culture marks how people behave now and how they are likely to behave in the future. Central to this definition is the idea of a shared understanding among those people who share a common identity. The performance of rituals or use of symbolic markers is essential in underpinning the symbolic meaning of these identities. They are part of the process of anchoring the abstract and changeable concept of identity. The effectiveness of the marker depends on the symbolic significance attached to it by group members. Barth (1969) argued that "often such features such as dress, language, house form, or general style of life" (p. 13), are overt signals or a sign of the group's identity and uniqueness. These symbols are given meaning through discourse, and film discourse plays (and has played since the origins of cinema) a paramount role in creating this collective identity.

Social identities therefore emerge as a collective practice. Identity surfaces when communities begin to do things together; indeed, identity facilitates the coordination of those activities that constitute a community. Collective identities are produced and reproduced through interactions that construct common realities attached to communal membership (Collins, 1981). One of the main approaches of public relations is as a process to construct meanings. Indeed, from a symbolic 
interactionist perspective, Zhang (2006) concluded that "public relations and symbolic politics are both a meaning-construction process through use of symbols, interactions and interpretations" (p. 27). In this process, cinema and filmmaking play a central role (Badiou, 2013).

In the process of building European identity, or in other words, the consciousness of belonging to a common geographical and cultural space, the wars waged across Europe in the last century helped spread the idea that the countries of the Old Continent could no longer remain isolated from events in neighboring states. The Spanish Civil War was the first significant conflict to enter the consciousness of all Europeans (Payne, 2012). Far from being just a national confrontation, it came to reflect the antagonistic conceptions of the very idea of European civilization: totalitarianism and democracy, idealism and social experimentation, internationalization and noninterventionism, which overlapped in all their complexity in the Spanish conflict.

Representation of the war in the media, especially in photography, radio broadcasts and film, implied a constant renewal of styles, as well as the use of propaganda techniques tried out and transmitted across the world (Taylor, 2003). Filmmaking developed as a result of innovations in form and language, and all factions used this during the War to further their cause by creating myths and social imagery (Ellul, 1973). Examples of this were the documentary and propaganda output of the Germans and Italians in support of their respective military uprisings, the prolific output of Soviet filmmakers, the independent British perspective and the North American viewpoint as given by New York intellectuals. From a public relations perspective, Kilborn (2006) pointed out that documentaries are one of the few audiovisual genres that offer a better understanding of how institutions operate. In his words: "It is only when one begins to consider the function of documentary in these terms that the full public relations potential of the genre can be appreciated" (p. 203). 
Among these film productions, the Republican propaganda films produced by the Spanish embassy in Paris under the supervision of Luis Buñuel are unique, differing from other propaganda films produced by the Republican faction during the Spanish Civil War. Our study focuses on (1) a selection of films produced by the Spanish embassy in Paris aimed at European audiences; (2) Buñuel's role in producing these films; and (3) the analysis of España leal en armas (1937) as an example of an ethical propaganda film, and consequently an example of public relations film discourse in wartime. The aforementioned film is important for understanding how film language was evolving and the crossbred style of the structure of propaganda. Furthermore, through these films Buñuel transmitted the values of their intended audience across Europe, in particular those of the French, via whom these films on the Spanish Civil War entered the European collective memory. Of equal importance is Buñuel's theoretical conception of documentary cinema in these films, and their hybridization with the traditions of Soviet cinematic propaganda and the British documentary schools of the 1930s. Consequently, in accordance with the arguments posited by Xifra and Girona (2012), these films are closer to public relations film discourse than propaganda discourse. Throughout this article, the term "propaganda" (and "ethical propaganda") is used to refer to a public relations technique as it was used in the specific historical context or original sources. As L'Etang (1999) stated, “although this might seem confusing, it is more historically authentic". Indeed, despite the above meaning, in the 1920s and 1930s public relations was quite often defined as a propaganda technique, even if after World War II this terminological hierarchy was reversed and propaganda came to be seen as one of the tools of public relations (L'Etang, 1999).

Nonetheless, before starting with discourse analysis, it is relevant to point out that Buñuel always underestimated his participation in España leal en armas — in fact, in his memories, Buñuel (1983) doesn't talk about the film. It was a political commission and possibly Buñuel, as he did with his films produced for the film production company Filmófono under the Spanish Second Republic, 
would not want to tarnish his reputation as a surrealist and independent filmmaker filming movies with clear political purposes.

On the other hand, film studies and film critics have not pay attention to the propagandistic work of Luis Buñuel. Just recently, Ruiz del Olmo (2010) and Gubern and Hammond (2012) have done research about them. Accordingly, this paper will try to fill this gap adding a new perspective, followed by other scholars (e.g. Xifra \& Girona, 2012; Quintana \& Xifra, 2016; Thomson, 2016): the public relations discourse one, instead of a "mixture of theoretical approaches and resulting methodologies that exist in film studies" (Thompson, 2016, p. 819).

\section{Republican faction propaganda films during the Spanish Civil War}

Scholars have recently taken more notice of films made for propaganda purposes during the Spanish Civil War (e.g. Gubern, 1977, 1986; Crussells, 2003; Kowalsky, 2003; Herrera, 2006; Sánchez-Biosca, 2006, 2007). The Republican faction was prolific in its production of propaganda films during the Civil War, despite uncertain beginnings: in 1936, propaganda was the responsibility of the Propaganda Section of the Ministry of Public Education and Fine Arts; a year later, it was transferred to the new Ministry of Propaganda when the government relocated to Valencia (García, 2009). Later, in May 1937, the government created the Undersecretariat for Propaganda, as part of the Ministry of State, which produced the bulk of the Republic's propaganda films (Gubern, 1977; Álvarez \& Del Rey, 2013).

Within this administrative chaos of wartime, the above governmental bodies attempted to bring all production of propaganda films under its control, while Buñuel's film workshop in Paris remained largely independent. In contrast to the films produced for Spain, the Republican propaganda films coming out of Paris were adapted for export, with the aim of presenting the Republic's claim to 
legitimacy in a balanced and objective way (Gubern et al., 1995). In addition, these films reflect Buñuel's theories and ideas on documentary making, which not only showed the tragic consequences of war but also projected the inherent difficulties of staying alive. As supervisor, he steered clear of fervid revolutionary sloganeering such as socio-economic justifications, and his stamp can be seen in many descriptive shots, which are serene but also psychologically charged to move the spectator to action or stir the conscience (Gubern \& Hammond, 2012). The documentary style emerging from Buñuel's workshop in Paris differed from the work produced by the propaganda section of the Ministry of State in Spain. The latter are films of three or four minutes' duration that rely heavily on effects. They are formally creative and aim for maximum impact by using montage and collage. They were short newsreels produced for projection at cinemas across the Republican zone, and their structure and content follow the Soviet canon on agitation and propaganda (Gubern et al., 1995).

When civil war broke out in mid-1936, Buñuel was in Madrid, and his attitude towards the resulting popular disturbances was ambivalent. On the one hand, he was carried along by the emotion surrounding the outbreak of war: the breakdown of the social order that he himself had advocated, first in Surrealism and later in Communism, were materializing before his eyes. However, the excesses soon shocked him. At the end of September 1936, he was summoned to Geneva by Minister Álvarez del Vayo, from where he was to travel to Paris to work at the Spanish embassy under ambassador Luis Araquistain (Pérez-Turrent \& De la Colina, 1993). He took charge of Republican film propaganda aimed at the French audience, although his other tasks at the embassy have remained a mystery (Gubern \& Hammond, 2012). Another of Buñuel's tasks during his exile in Paris was to provide assistance and support for propaganda films produced inside Spain, including André Malraux’s Days of Hope or Man's Hope (1938-39) and Joris Ivens' The Spanish Earth (1937). The Republican government provided Buñuel with considerable filmmaking 
resources and had recruited directors and intellectuals to the Republican cause, such as Ivens, Ernest Hemingway and Norman McLaren, among others (Ruiz del Olmo, 2010).

Two Soviet cameramen, Roman Karmén and Boris Makaseiev, arrived in Spain on August 23, 1936 to document the conflict as part of the Soviet Union's strategic interest in the outcome of the war and the Popular Front strategies of the Komintern. They produced considerable material, which was subsequently put to many different uses: firstly, as newsreels, together with scripts written by Koltzov, for the series Events in Spain, which was shown in cinemas across the Soviet Union between September 1936 and July 1937. The work done by Karmén and Makaseiev was extensive, varied and paid great attention to detail, going beyond propaganda to examine daily life in wartime and the human emotions aroused by the conflict. Their material was also put to use, in a more balanced and objective way, in medium-length films made under Buñuel's supervision and, as Sánchez-Biosca (2007) has argued, the Soviet cameramen shot some of the most striking images that exist of the Republican defense of Madrid.

Of all the Republican propaganda films coming out of Paris, one of the most remarkable was España al día: España 1936 (Espagne 1937, in France). In Spain, the film was entitled España 1936 or Madrid 36, as most of the film action takes place in the capital. It was also named España leal en armas - a more rhetorical title that more accurately reflects the purposes of the documentary — by Ado Kyrou (1963) in one of the first Buñuel biographies.

The importance of the work done at Buñuel's workshop in Paris also lies in how editing and archiving were employed in documentary films. As Reisz (1960) argued these are a type of nonfiction film that mix and order archive footage or film made especially for a past or present event in order to construct a new meaning. As Koningsberg (1987) noted, this intellectual task of filmmaking must necessarily entail a metamorphosis, adding quality to the final artistic product. 
From another perspective, Bordwell and Thompson (2009) consider it a historical documentary style used in certain periods, such as wartime, or for ideological propaganda during the Spanish Civil War or World War II or the more existentialist and politicized cinema of the 1960s and 1970s. Certainly, there are similarities between these films and techniques of propagandist collage and photomontage, one of the most active practitioners of which during the Civil War was the revolutionary communist Josep Renau, the best known propaganda artist of the Spanish Republic. In this kind of film, any material, original or borrowed, justifies the ends of sensitizing international public opinion to the illegitimacy of the military uprising and the just cause of the Republican government, and fomenting a change in the non-intervention policy penalizing it.

This policy did not conflict with Buñuel's artistic impulse. In fact, in his creative phase just prior to working in Paris, he produced several commercial films as a member of the Filmófono production company owned by his friend Ricardo Urgoiti, becoming a Hollywood-style executive producer in 1935-36 surrounded by a team of collaborators and controlling the financial as well as creative aspects of films like Don Quintín el amargao (Luis Marquina, 1935), La hija de Juan Simón (José Luis Sáenz de Heredia, 1935), Centinela alerta (Jean Gremillon, 1936) and Quién me quiere a mi (José Luis Sáenz de Heredia, 1936).

Many of these films were shown at venues run by the then powerful French Communist party, as well as being presented at the Spanish pavilion in the International Exposition held in Paris in 1937 in a film cycle organized by Buñuel itself. However, España leal en armas is without doubt a unique work thanks to its collective collaboration: Buñuel's ideas on documentary making merge with techniques of Soviet agitprop, while also acknowledging US documentary makers and intellectuals, contributions from a nucleus of New York intellectuals such as John Dos Passos, Ernest Hemingway, Leo Hurwitz, Paul Strand, among others, within the context of the New Deal; ideals that are more often romantic than a reflection of effective social commitment (Martin- 
Hamdorf, 1995). All of these factors are assembled within the context of the Civil War, where ideologies and utopias clash on an international level.

The films made by American directors and the propaganda films of the Spanish embassy in Paris differ in their treatment but share a similar strategy of raising awareness among American and French public opinion to lift the arms embargo against the Republic. One typical example is The Spanish Earth produced by Contemporary Historians, Inc., a company formed and funded by several cultural figures, including Lillian Hellman, Ernest Hemingway, John Dos Passos, Dorothy Parker, and Archibald MacLeish, and directed by Joris Ivens in 1937 with camera operator John Ferno. This documentary deals not only with the need to redistribute land but also with the defence of Madrid, using a narrative, dramatic and fictional documentary technique that lacks balance but is nevertheless very passionate. As Ruiz del Olmo (2010) suggests, España leal en armas is a more balanced work and closer to the idea of historical truth.

\section{España leal en armas (1936)}

Produced by Cine-Liberté, the production company associated with the French Communist party, this is a medium-length film with images taken, as mentioned previously, from many and various sources: part of the material had already been filmed by Karmén, and other images came from Manuel Villegas and other anonymous Spanish cameramen. The film was edited by French filmmaker Jean Le Chanois, and the audio commentary was read by Gaston Modot, the lead actor in Buñuel's surrealist film L'âge d'or (1930). The text narrated by Modot was written by Buñuel and Pierre Unik, whom Buñuel had worked with on Law without bread (1932). Buñuel also chose the film score, which exerts a substantial symbolic effect on the film, including excerpts from Beethoven's 7th and 8th Symphonies. 
Buñel provided the production company with audiovisual material and funding to make the film, as well as supervising the final product (Aranda, 1976). At this point, the film structure was a selection of documentaries from which he chose a set of images in line with the film's didactic tone, explicative, but apparently neutral and objective, with the aim of gaining international support for the Republic. Five clearly visible strands run throughout the film, of varying importance and duration. A simplistic description of them would be the fall of the monarchy and the first reforms, the military uprising and the War, the Battle of Irun, domestic and foreign action by the Republican government, and the Madrid front. Each differs in length and structure according to the contrasting film material and documentary sources used. The final section is the longest - hence the film also being entitled Madrid 1936 - and includes a preamble that establishes analogies between the Madrid front and Verdun to motivate French intervention in Spain. It also contains a general epilogue as a final reflection on the entire film, with highly symbolic images relating to the idiocy of war and the solitude of the human condition. The conclusion is shocking and contradictory, with several spoken messages that deviate from the film's objectives of Soviet-style propaganda, calling for French intervention and listing the Republic's reforms and social achievements in order to draw the audience onto a more humanistic and reflective terrain.

Following the description by Ruiz del Olmo (2010), the first part of the film uses techniques more closely related to reporting and newsreels. Indeed, the first part feels like a collage that starts off in a very neutral tone to acquire more propagandistic touches as it develops. It mixes the image of a monarchical statue appearing upside down as the camera turns and others depicting changes made under the Republic, such as the reform of the Army and agrarian reform in the image and likeness of the French model, as well as election posters, maps, etc. These printed documents carry a demonstrative value that establishes credibility for what is about to unfold in the eyes of the audience. Throughout the film, the tone is calm, restrained even, with the occasional exception, and 
highly didactic when relating the events of the War, in particular in the initial images that describe its causes, starting with the downfall of the monarchical regime. The formal resources of Soviet avant-garde cinema and Eisenstein's advances in montage are also visible. Shots charged with symbolism emerge now and then to break the somewhat monotonous tone. An equestrian statue representing the monarchy is turned on its head to symbolize the successes of the Second Republic (Figure 1): education, the reform of the Army, the Statute of Catalonia, the elections and the increasing participation of women in public life. The film avoids fervid revolutionary causes or slogans and visually emphasizes the illegality of the military uprising, using the outbreak of war and the figure of Franco and other military mutineers as a counterpoint. Headlines (July 17, 1936) and explanatory maps recur, their function being both informative and to reinforce the credibility of the narrative. Thus, this part is closer to a public relations discourse than a propaganda one (Quintana \& Xifra, 2016).

\section{Insert Figure 1 here}

In terms of its documentary style, the film adopts a successful counterpoint between the more obvious Soviet agitprop, together with the symbolism and avant-garde editing of directors like Eisenstein, and a particular psychological description and poetic reading that appears to come from Buñuel's own documentary conceptions. The film's link to Battleship Potemkin (Sergei M.

Eisenstein, 1925) is clear. Buñuel admitted that the Republican government commissioned him to make a propaganda film in the style of Eisenstein's masterpiece in August 1936, but the assignment was unrealistic: financial and technical difficulties meant it was impossible to shoot or even stage the film within the timescale required. Buñuel also believed Spanish films about the Civil War should simply record events in all their harsh reality and distance themselves from epic storytelling and myth-making (Martin-Hamdorf, 1995). He settled on documentary realism, which by no means excluded raising awareness, poetry and expressive symbolism. In addition, he had a method and 
production routines that had to be adapted to the context and immediacy of the serious events unfolding in the War and overcome technical problems and a lack of funds. This meant using and reusing materials from many different sources and making the most of the resources available to realist films, which were not short of formal expressive qualities: symbolic or poetic shots; short narrations to intensify the commentary; contrasting the feelings of individuals with those of the masses and the collective; the way of using camera angles, and eliciting certain effects through movement.

The second section of the film narrates the unfolding of the military uprising and its consequences, depicting the zones controled by the two sides and civilian life in both. Then there are images showing Franco's forces, the Phalange, the regular army and the Moroccan troops alongside the mobilization of the population in defence of the Republic. The first effects of the War are apparent here, and the images convey not some distant conflict but general shots of buildings in ruins followed by still images and close-ups of windows and homes: this is a war that is close and familiar. Ideological extremes are accentuated in the polarization of how combatants on both sides are represented visually: Franco's Spain is always shown as a rigid military organization, a rigidity that also characterizes civil life; there are contrasts between shots of large bustling Republican crowds and the martial rigidity of Franco's civil society; images of the Republican faction show the warm, human, spontaneous enthusiasm of the crowd supporting the Republic, the organization of the people's army with fighters eager to join up, impassioned by the fight for a just cause (Figure 2) and a sense of responsibility and common effort, reinforced by the film score. Many of the images and their sequencing follow Soviet agitation and propaganda (agitprop) techniques. 
From this perspective, the film is aligned with Grierson's idea of documentaries as a tool for social action and a key source of social change. The main focus of his thinking on the documentary and public relations could be described as "social or democratic education, the role of propaganda, and social responsibility, and it is echoes of these that can be detected in public relations discourse" (L'Etang, 2006, p. 32). From this perspective, España leal en armas is an example of this public relations discourse, as the third part confirms.

Indeed, the next part contains one of the first battles to have been fought in the War, which was significant due to the warfare techniques employed by Franco. It shows the siege and taking of Irun by Franco's troops and the aftermath. The Battle of Irun informs international public opinion that the conflict is one-sided in terms of troop numbers and material. It depicts the Nazi war machine at work in the Basque Country and the terrible consequences of the fall of Irun. Without directly stating the fact, this imbalance in forces is a metaphoric call for military aid for the Republic to give it a fighting chance. The consequences are dramatically portrayed in the visual strength of the image of the city in flames at night, people filing into exile and the French trains that have to return to Hendaye. As the film progresses, highly symbolic elements appear in greater number, reinforced by the film's construction: the destruction of the city and subsequent repression, and the first exiles. Dramatic resources are numerous: civilians fleeing bombardment, explosions, people looking skywards warning of an aerial bombing, the destruction of buildings and fires. The commentary ceases and all that is heard is an ambient diegetic sound, of flames, explosions or the silence of people tramping into exile. The symbolism makes the viewer stop and think, alternating with an anti-fiction and non-formal realism that Buñuel was advocating at the time as a guarantee of truth in the documentary. The elements of agitation and motivation for French intervention are apparent in the reconstruction of executions by firing squads and political repression. The death of two French 
journalists is a key resource in the film's objective of breaking the Western democracies' nonintervention policy.

A fourth section of the film focuses on legitimacy and the just, i.e. balanced and not fervently revolutionary, actions taken to safeguard the people and the government of the Spanish Republic. As is usually the case in the rest of parts of the film, this section uses graphics as well. Thus, the didactic aim is always present, showing the political parties that backed the Republic and the government of Socialist president Francisco Largo-Caballero. It was important for international public opinion to see that civilian life under the Republic was normal, with no hint of revolutionary disturbance or unrest. The daily life we see is thus peaceful, orderly and pleasant: farmers at work, uninterrupted public transport and communications, children at school, the training of the people's army. Therefore, the message is clear - what the War is threatening to destroy is a life of progress and freedom.

The fifth and final section of España leal en armas portrays the frontline defense of Madrid. It starts with a map depicting a pincer movement closing in on Madrid. Then we see a placard with the words "No pasarán" (They shall not pass"), and images of civilians and Republican politicians (Figure 3). The French audience is warned that the Madrid front is about to become another Verdun: the capital will resist, with self-sacrifice and faith in victory but there is no hint of epic storytelling. The film score enhances the monstrous reality of the daily lives of citizens and their defenselessness by using the sounds of sirens, ambulances and explosions. As a counterpoint, silence is also deployed to dramatic effect in the bombing sequences, with buildings in flames, bomb craters and buildings collapsing, the bodies of women and children abandoned in rooms full of coffins. 
This section of the film centered on Madrid is pervaded with a certain poetic realism and, quite often, with extreme pessimism which naturally sits awkwardly with the Soviet agitprop reporting There are yet more resources at work to convey authenticity, such as milestones, placards in Madrid and the frontline at the Casa de Campo, the park on Madrid's outskirts. Another element that injects dynamism and reality are the short fictional tales that heighten the film's dramatic feel; for instance, when some parents visit their son who is fighting on the front. The organization of life in Republican Madrid and the defense of the capital are seen in terms of full civilian cooperation, a collective effort. Even children play their part. Childhood is a recurrent theme in the film, amply reflected in images of children at school and as active defenders of the Republic. Nothing seems to be left to chance: artistic treasures are removed for safekeeping; underground stations are used as air-raid shelters.

The film ends by addressing the audience in more agitprop terms. The person filmed in close-up standing alone in contemplation and the absurdness of barbed wire wrapped around wasteland make for a poetic statement on the human condition and the horrors of war. The commentary closes with the question: "When will this monstrous war end?" There are no heroic rallying calls or depictions of enthusiasm on the part of combatants. As Xifra \& Girona (2012) claim with regard to Frank Capra's documentary series Why We Fight? (1942-1945), the rhetorical construction based on questions suggests a didactic purpose, offering a dynamic based on discussion, on contrasting opinions. This type of rhetoric is very typical of strategies in crisis communication: "The crisis response and post-crises communications seek to inform stakeholders (instructing information) and to persuade stakeholders" (Coombs, 2009, p. 241). 


\section{Conclusions}

Despite including staging elements typical of propaganda films (inspired mainly in S.M. Eisenstein's 1925 film, Battleship Potemkin), the narrative resources used in España leal en armas veer away from propaganda discourse. They are closer to an audiovisual discourse more characteristic of public relations, as Grierson understood it (L'Etang, 1999, 2000). John Grierson, father of the British documentary movement (also greatly influenced by Eisenstein) and a public relations practitioner who approached propaganda from a public relations perspective (L'Etang, 1999), stated with regard to propaganda:

\footnotetext{
"There are some of us who believe that propaganda is the part of democratic education which education forgot... We believe that education has concentrated so much on people knowing things that it has not sufficiently taught them to feel things. . We can, by propaganda, widen the horizons of the schoolroom and give to every individual each in his place and work, a living conception of the community which he has the privilege to serve. We can take his imagination beyond the boundaries of his community to discover the destiny of his country. We can light up his life with a sense of active citizenship. We can give him a sense of greater reality in the present and a vision of the future" (cited in Marlin, 2002, p.
} 21).

España leal en armas fits into this idea of propaganda, or more accurately ethical propaganda (St. John, 2006). The same is true of the other Republican films supervised by Luis Buñuel - their cinematographic language and instructions are important parts of European identity. Not only due to the enormity and consequences of the conflict but also the essentially didactic tone of the films we have analyzed: those Buñuel produced at the Spanish embassy in Paris aimed at influencing European public opinion. 
These are films that rely heavily on editing, made with archive footage, that is, material from various sources, some of which are often far removed from the propaganda films of the time. As ethical propaganda products, in the audience's eyes this strengthens the supposed objectivity and credibility of the theses proposed by the discourse, which are the legitimacy and social justice represented by the Republican government, the dignity of its supporters and the need to come to its aid in the conflict. The photography displays a great variety of style, with close-ups of objects and faces that enhance the symbolism and identification of the spectator with the protagonists together with emotive micro-fictional tales.

As aforementioned, documentaries are one of the few audiovisual genres that serves to canalize public relations discourse (Kilborn, 2006). España leal en armas —like Frank Capra's Why We Fight (Xifra \& Girona, 2012) and other documentaries made during wartime - is an example of public relations discourse in war times and can be considered a model of the practice of ethical propaganda in the sense expressed by Ivy Lee (St. John, 2006). Thus, Luis Buñuel should rightly be considered as forming part of the group of documentary makers who, like John Grierson, Paul Rotha, Joris Ivens, Frank Capra, Jean Renoir or even Alfred Hitchcock -who acted as a "treatment advisor" on the British documentary Memory of the Camps (1945) (Gladstone, 2005)- have played an important role in creating a rhetorical and audiovisual dimension to public relations, and particularly in the production of educatory documentaries like España leal en armas. John Grierson, the public relations practitioner who coined the term "documentary film", saw educatory films as an instrument of social action and a key source of social change: "if you can't teach the citizenry to know everything all the time, you can give them comprehension of the dramatic patterns within a living society" (Grierson, cited in Marlin, 2002, p. 21). This statement seems to have inspired all the aforementioned filmmakers. 
España leal en armas is an example of ethical contribution to propaganda for the purpose of achieving French and European intervention in the Spanish Civil War. From this point of view, the film production system employed by the Second Spanish Republic was an instrument of public communication in which the images of what was really happening were a crucial element of the disseminated message. In this sense, Buñuel's film was closer to a newsreel than a propaganda film. Thus, España leal en armas is also a good example of the use of cinema for public relations purposes in order to educate and raise French and European awareness of Franco's troops' war activities and their consequences ar the beginning of the Spanish Civil War.

During the Spanish Civil War and the years leading up to it, documentary film -including screen magazines and newsreels- represented an important public relations technique aimed at informing and raising forigners' awareness of the activities of Franco's troops and their establishing of a totalitarian regime during a tumultuous period in European history, which witnessed the emergence of fascism in Italy and Nazism in Germany.

At the beginning of the twentieth century, this new form of mass media, cinema, served the propaganda aims of the new totalitarian regimes, especially during the Russian revolution and the following years. This article has shown how the popularity of cinema turned it into the most effective tool for expressing information, ethical propaganda and public relations in order to fight against the negative propaganda of totalitarian countries and groups. In fact, the truth-telling strategy that dominated government news bulletins in cinema -particularly documentary cinema, the main channel via which it conducted its public relations function-and España leal en armas is aligned with an audiovisual language which inspired future war public relations efforts to generate concern regarding the dangers and risks of the political situation in Europe. 


\section{References}

Ávarez, M., \& Del Rey, F. (2013). The Spanish Second Republic Revisited: From Democratic Hopes to Civil War (1931-1936). Eastbourne, UK: Sussex Academic Press.

Aranda, J. F. (1976). Luis Buñuel: A critial biography. New York, NY: De Capo Press.

Badiou, A. (2013). Cinema. Malden, MA: Polity Press.

Barth, F. (1969). Ethnic groups and boundaries: The social organization of culture difference. Boston, MA: Little, Brown.

Bordwell, D., \& Thompson, K. (2009). Film art: An introduction. New York, NY: McGraw-Hill.

Buñuel, L. (1983). My last sight. New York: Albert A. Knopf.

Collins, R. (1981). On the microfoundations of macrosociology. American Journal of Sociology, 86(5), 984-1014.

Coombs, W.T. (2009). Crisis, crisis communication, reputation, and rhetoric. In R.L. Heath, E.L. Toth, \& D. Waymer (Eds.), Rhetorical and critical approaches to public relations II (pp. 237-252), New York: Routledge.

Crusells, M. (2003). La guerra civil española: cine y propaganda. Barcelona, Ariel.

Ellul, J. (1973). Propaganda: The formation of men's attitudes. New York: Vintage Books. 
García, H. (2009). La propaganda exterior de la República durante la Guerra Civil: Origen, éxitos y miserias de los servicios de París. Mélanges de la Casa Velázquez, 39(1), 215-240.

Geertz, C. The Interpretation of Cultures: Selected Essays, New York: Basic Books, 1973.

Gladstone, K. (2005). Separate intentions: The Allied screening of concentration camp documentaries in defeated Germany in 1945-46: Death Mills and Memory of the Camps. In T. Haggith \& J. Newman, J., Holocaust and the moving image: Representations in film and television since 1933 (pp. 50-64). London: Wallflower Press.

Gubern, R. (1977). El cine sonoro en la II República (1929-1936). Barcelona: Lumen.

Gubern, R. (1986). 1936-1939: la guerra de España en la pantalla. Madrid: Filmoteca Española.

Gubern, R., \& Hammond, P. (2012). Luis Buñuel, the red years: 1929-1939. Madison, WI: University of Wisconsin Press.

Gubern, R.; Monterde, J. E.; Pérez-Perucha, J; Riambau, E., \& Torreiro, C. (1995). Historia del cine español. Madrid: Cátedra.

Herrera, J. (2006). Estudios sobre Las Hurdes de Buñuel. Seville: Renacimiento.

Kilborn, R. (2006). A marriage made in heaven or in hell? Relations between documentary filmmakers and PR practitioners. In J. L’Etang \& M. Pieczka (eds.), Public relations: Critical debates and contemporary practice (pp. 187-204), New York: Lawrence Erlbaum. 
Konigsberg, I. (1987). The complete film dictionary. London: Bloomsbury.

Kowalsky, D. (2003). La Unión soviética y la guerra civil española: Una revisión crítica. Barcelona: Crítica.

Kyrou, A. (1963). Luis Buñuel: An introduction. New York, NY: Simon \& Schuster.

L'Etang, J. (1999). John Grierson and the public relations industry in Britain. Screening the past: An international electronic journal of visual media and history. Retrieved 29 September 2016 from http://www.latrobe.edu.au/screeningthepast/firstrelease/fr0799/jlfr7d.htm

L'Etang, J. (2000). John Grierson and the public relations industry in Britain. In J. Izod, R. Kilborn, \& M. Hibberd (Eds.), From Grierson to the docu-soap (pp.83-94). Luton: University of Luton Press.

L'Etang, J. (2006). Public relations and propaganda: Conceptual issues, methodological problems, and public relations discourse. In J. L'Etang \& M. Pieczka (Eds.), Public relations: Critical debates and contemporary practice (pp. 23-40), New York: Lawrence Erlbaum.

Marlin, R. (2002). Propaganda \& the ethics of persuasion. Peterborough, Canada: Broadview Press.

Martin-Hamdorf, W. (1995). Espagne 1936, y Espagne 1937: propaganda para la Republica (Luis Buñuel y la Guerra Civil española). Secuencias: Revista de Historia del Cine, 3, 86-95. 
Payne, S. G. (2012). The Spanish Civil War. New York, NY: Cambridge University Press.

Pérez-Turrent, T., \& De la Colina, J. (1993). Buñuel por Buñuel. Madrid: Plot.

Quintana, Á., \& Xifra, J. (2016). Visual-spatial intelligence in propaganda and public relations discourse: The case of Roberto Rossellini's early and educational-historical films. Public Relations Review, 42(2), 288-297.

Reisz, K. (1960). The technique of film editing. London: Focal Press.

Ruiz del Olmo, F.J. (2010). Lenguaje e identidad colectiva en Buñuel: Propaganda en el filme “España 36”. Comunicar, 35(18), 69-77.

Sánchez-Biosca, V. (2006). Cine y guerra civil española. Del mito a la memoria. Madrid: Alianza.

Sánchez-Biosca, V. (2007) Propaganda y mitografía en el cine de la guerra civil española (19361939). Cuadernos de Información y Comunicación, 12, 75-94.

St. John, B., III. (2006). The case for ethical propaganda within a democracy: Ivy Lee's successful 1913-1914 railroad rate campaign. Public Relations Review, 32(3), 221-228.

Taylor, P. M. (2003). Munitions of the Mind: A history of propaganda from the ancient world to the present era. Manchester, UK: The Manchester University Press ( $3^{\text {rd }}$ ed.).

Thompson, G. (2016). The Next of Kin: Propaganda, realism or a film with a purpose? Public Relations Review, 42(5), 812-820. 
Xifra, J., \& Girona, R. (2012). Frank Capra's Why We Fight and film documentary discourse in public relations. Public Relations Review, 38(1), 40-45.

Zhang, J. (2006). Public diplomacy as symbolic interactions: A case study of Asian tsunami relief campaign. Public Relations Review, 32(1), 26-32. 